\title{
Rating system Establishment Conditions in the Higher Educational Institutions and its Tendencies of Development in the Republic of Uzbekistan
}

\section{Zakhidova Shirin}

\begin{abstract}
The article highlights the measures taken to improve the quality of higher education, which is one of the key drivers of economic development, and of Uzbekistan's higher education institutions to enter the global top 500 universities.
\end{abstract}

Keywords: Higher education system, rating, quality of education, universities, world universities, educational export, scientific potential.

\section{INTRODUCTION}

Implementation of the economy through the improvement of the quality of higher education, increasing the prestige of higher education institutions and increasing the export of education is one of the key factors in the development of each sector.

Great work is being done all over the world. At the same time, Uzbekistan is implementing inter-institutional efforts to enter the global top 500 universities in the country.

Methodology. Systematic approach, comparative and structural analysis, grouping methods were used in the writing process.

The degree to which the literature is studied. The fundamental and practical aspects of the development of the higher school were studied in the scientific works of foreign scientists V.V Zapolskaya and V.A Noskov. . Some aspects of the state and development of the education system in Uzbekistan in the years of independence Analytical works of A. Seitkhalilov, S.E Kurbonov. Much of the above research is devoted to the study of the mechanisms of financing and marketing, management of higher education.

On December 29, 2012 the Resolution of the Cabinet of Ministers of the Republic of Uzbekistan № 371 was aimed at improving the quality of research work, bringing the level of pedagogical activity to international standards, improving the quality of education and training of personnel, and strengthening international contacts. Based on this decision, the rating of the higher education system will be evaluated according to the following indicators:

1. $35 \%$ - questionnaire on quality of teaching, teacher qualification, quality of education among students, number of

Revised Manuscript Received on July 22, 2019.

Zakhidova Shirin, National University of Uzbekistan textbooks published by professors, ratio of foreign students and teachers, exchange programs with foreign universities, implementation and application of ICT.

2. $20 \%$ - Assessment of employers' alumni capacity through questionnaires, number of graduates employed within six months after graduation, international degrees earned by students and alumni.

3. $35 \%$ - scientific potential is determined by the number of articles published and quoted, the number of doctoral dissertations, and the income from research activities.

4. 10\% - other factors: access to information, ICT application, Internet access and communication with schools.

Decree of the President of the Republic of Uzbekistan dated July 27, 2017 № PP-3151 "On measures to further increase the participation of sectors and sectors of the economy in improving the quality of training specialists with higher education", according to the State Inspection on Education Quality By the decision of the Ministry of Higher and Secondary Special Education:

1. Regulations on the procedure for determining the rating of higher education institutions

confirmed.

2. Based on this Regulation, the rating of higher education institutions on indicators of quality of education as a pilot in 2017-2019 was determined.

The purpose of the rating is to stimulate the level and quality of scientific and pedagogical activity of the higher educational institutions of the republic, to use the scientific potential of the teaching staff in higher educational institutions and to meet high international standards and quality of training. expanding international cooperation in the field of education, including higher education, which has achieved good results in the national rating system Bee separate legal acts of the training process, an independent authority to review and approval by the academic freedom to provide step-by-step introduction.

This unit has the following tasks:

- Preparation of highly qualified specialists required on the labor market of the Republic on the basis of continuous 
improvement of higher education;

- Providing the competent authorities, education personnel and the general public with objective information about the quality of educational services provided in higher education institutions, their scientific and educational processes and opportunities;

- ensuring cooperation of higher educational institutions of the country with the world universities with high ratings and achievement of high international standards in the system of higher education of the republic.

The rating of higher education institutions is determined by observance of the norms of objectivity, full transparency, periodicity and ethics. The State Inspection on Education Quality Control under the Cabinet of Ministers of the Republic of Uzbekistan and the Ministry of Higher and Secondary Special Education should continually improve the methodology for determining the rating of higher education institutions, with a thorough analysis of the dynamics of development of higher education in the country. Ministries and departments, which have higher education institutions under their jurisdiction, are planning to submit their proposals and comments to the State Inspectorate every year by February 1 on improving the rating methodology.

\section{THE PROCEDURE FOR DETERMINING THE RATING OF HIGHER EDUCATIONAL INSTITUTIONS OF THE REPUBLIC OF UZBEKISTAN}

I. The scientific activity of professors - 65 points

Percentage of professors and teachers with $\mathrm{PhD}$ and DSc (1000\% of total number of academic degree and title) in 1000 most prestigious universities of the world - 4 points.

- Share of professors and teachers participating in lectures (seminars, workshops, trainings) in the top 1000 most prestigious universities of the world (in \% to the total number) in the year of ranking - 4 points.

- Academic capacity of professors - 5 points (in\% of main staff), including:

1. Percentage of Professor Teachers with Doctor of Science (DSc) - 3 points.

2. Percentage of Professor Teachers with $\mathrm{PhD}$ degree -2 points.

1. Effectiveness of doctoral thesis defense: - 9 points.

2. The percentage of defenders this year is 4 points.

3. The percentage of defenders in the last year is 3 points.

4. The percentage of those who defended their doctoral thesis under the guidance of a professor of the university (current and last year) - 2 points.

- Quotations of university professors publications according to international indicators, including 6 points:

1. In Uzbek and in CIS - 2 points.
2. In foreign languages - 4 points.

Number of articles and monographs (per 1 professor), published in international scientific journals, local scientific publications (included in the list of HAC), 8 points:

1. Scientific articles in international journals (HAC lists and journals with impact factor) -3 points.

2. Published monographs -3 points.

3. Scientific articles in the national scientific journals (HAC) -

2 points.

- The amount of funds received on the basis of the results of research and presentation of the results of research to the practice (per one professor), 8 points:

Funds received from grants of foreign research centers and applications of foreign scientific funds (per 1 professor-teacher) - 3 points.

Funds received from research (scientific and creative) research in the field (per one professor) - 3 points.

Research grants based on government grants (per 1 professor) - 2 points.

Funds received under license agreements - 1 point.

Efficiency of research works - 8 points:

1. The number of protection documents (patents) received from intellectual property objects -3 points.

2. The amount of scientific research applied to practice (based on normative documents approved by the relevant organizations) - 2 points.

3. Number of license agreements based on results of intellectual property - 3 points.

Share of professor Teachers, who won prize-winning places in international and republican prizes and awarded diplomas 5 points.

1. Internationally - 3 points.

2. Republican - 2 points.

- Determining the level of knowledge of professors and teachers, teaching foreign languages and information and communication technologies, including 8 points:

1. Subject - 4 points.

2. For foreign languages - 2 points.

3. Information and Communication Technologies - 2 points.

\section{THE QUALITY OF TEACHING-METHODICAL WORK AND TEACHING IS 57 POINTS..}

Quality of teaching - 9 points (based on lesson analysis and student survey results), including:

1. Conditions for Education (based on the questionnaire) - 3 points.

2. Lesson quality (based on lesson analysis and questionnaire) -5 points.

3. Objective assessment of students' knowledge (based on the questionnaire) - 1 point.

- Textbooks and manuals written and published by the faculty of the HEI, 25 points, including:

1. Textbooks - 15 points.

2. Textbooks - 10 points. 
The percentage of foreign teachers and students ( $\%$ of the total), 10 points:

1. Foreign teachers - 5 points

2. International students -3 points.

3. Diversity of foreign students - 2 points.

Participation of teachers and students in exchange programs with foreign universities, 10 points, including:

1. Academic Exchange (by students) - 5 points.

2. Participation in scientific, educational projects (foreign, joint) - 3 points.

3. Participation in international conferences, seminars - 2 points.

Number of subjects taught in a foreign language in the direction of specialization (\% of the total) -3 points.I

\section{STUDENT KNOWLEDGE AND QUALITY OF GRADUATES - 53 POINTS}

Assessment of senior students' knowledge in special subjects 25 points.

- Graduate employment after graduation - 10 points.

- Number of students who have won prizes and awards (diplomas) at international and national Olympiads and prestigious contests, including 8 points:

International level - 6 score.

Republic level - 2 score.

- Level of admission of academic lyceums under the higher educational institutions at the university is 5 points.

- Failure of young professionals (weight of young professionals who have been dismissed from the university for the last 3 years, \%) *) - Under 35 - 5 points.

\section{LOGISTICAL SUPPORT OF THE EDUCATIONAL PROCESS, USE OF ICT, ETC. - 15 POINTS}

- Provision of educational process with modern computer equipment and educational presentation equipment -5 points, including:

1. The percentage of computers used by students in the learning process -3 points.

2. Share of classrooms equipped with modern teaching and presentation equipment, specially equipped classrooms - 2 points.

- Level of equipping laboratory facilities of the university with the necessary equipment and equipment for laboratory studies, in $\%$ - 5 points.

- The quality of the website of the university on the Internet (availability of necessary information about HEIs, publications and materials, contact information for electronic requests of users, page updating, etc.) - 5 points.

Ranking of Universities Web Universities Web System Rankings in Universities - 3 points.

Ranking of higher educational institutions web-site in www.uz national search engine - 2 points.

\section{SUMMARY}

The rating of higher education institutions is objectivity, full transparency, and regularity and ethical standards. The State Inspection on Education Quality Control under the Cabinet of Ministers of the Republic of Uzbekistan and the Ministry of Higher and Secondary Special Education constantly improve the methodology for determining the rating of higher education institutions, analyzing changes in the international practice of rating higher education institutions. Ministries and departments, which have higher education institutions under the jurisdiction of the Cabinet of Ministers of the Republic of Uzbekistan annually submit their comments and suggestions on improvement of rating methodology by February 1

Annually the State Higher Education Inspectorate under the Cabinet of Ministers of the Republic of Uzbekistan is the rating of HEIs.

Rating results up to March 1 of each year:

It is published in the newspapers Marifat and Uchitel Uzbekistana. State and Ministry of Higher and Secondary Special Education.

\begin{tabular}{|c|c|c|}
\hline \multicolumn{3}{|c|}{$\begin{array}{c}\text { Ranking of Social and Humanitarian Higher } \\
\text { Education Institutions }\end{array}$} \\
\hline № & HEI name & $\begin{array}{l}\text { Rating (from } \\
100 \text { score) }\end{array}$ \\
\hline 1. & $\begin{array}{l}\text { National University of } \\
\text { Uzbekistan }\end{array}$ & 62,82 \\
\hline 2. & $\begin{array}{l}\text { Toshent State Institute of } \\
\text { Oriental Studies }\end{array}$ & 57,97 \\
\hline 3. & Samarkand State University & 47,31 \\
\hline \multicolumn{3}{|c|}{$\begin{array}{l}\text { Rankings of Higher Education Institutions in Arts, } \\
\text { Culture and Sports }\end{array}$} \\
\hline № & HEI name & $\begin{array}{l}\text { Rating (from } \\
100 \text { score) }\end{array}$ \\
\hline 1. & $\begin{array}{l}\text { Uzbekistan State Institute of } \\
\text { Physical Culture }\end{array}$ & 41,60 \\
\hline 2. & $\begin{array}{l}\text { State Conservatory of } \\
\text { Uzbekistan }\end{array}$ & 40,69 \\
\hline 3. & $\begin{array}{l}\text { Higher School of National } \\
\text { Dance and Choreography }\end{array}$ & 35,68 \\
\hline \multicolumn{3}{|c|}{ Ranking of Medical Higher Education Institutions } \\
\hline № & HEI name & Rating (from \\
\hline & $\begin{array}{l}\text { Published By: } \\
\text { Blue Eyes Intelligence Engineering } \\
\& \text { Sciences Publication }\end{array}$ & \\
\hline
\end{tabular}




\begin{tabular}{|c|c|c|}
\hline & & 100 score) \\
\hline 1. & Tashkent Medical Academy & 47,03 \\
\hline 2. & Tashkent State Dental Institute & 46,18 \\
\hline 3. & $\begin{array}{l}\text { Tashkent Pediatric Medical } \\
\text { Institute }\end{array}$ & 43,11 \\
\hline \multicolumn{3}{|c|}{$\begin{array}{l}\text { Rating of higher education institutions in the fields of } \\
\text { technology, technology, construction and agriculture }\end{array}$} \\
\hline № & HEI name & $\begin{array}{l}\text { Rating (from } \\
100 \text { score) }\end{array}$ \\
\hline 1. & $\begin{array}{l}\text { Tashkent Institute of Irrigation } \\
\text { and Engineers of Agricultural } \\
\text { Mechanization }\end{array}$ & 55,38 \\
\hline 2. & $\begin{array}{l}\text { Tashkent Institute of Textile and } \\
\text { Light Industry }\end{array}$ & 52,97 \\
\hline 3. & $\begin{array}{l}\text { Tashkent Institute of Railway } \\
\text { Engineers }\end{array}$ & 46,00 \\
\hline
\end{tabular}

\section{RESULTS}

This paper gets results on rating system of the Republic of Uzbekistan while making analyses of the current conditions in higher educational institutions as the whole. Last but not the least, it receives overall view of the assessment points on different research and educational areas.

\section{REFERENCE}

1. Akhunova G.N Marketing activities in the educational services market and its improvement: dissertation for the degree of Doctor of Science T .: 2004. -45 p.

2. A. Vakhabov, E. Imamov. Higher education in Central Asia. The challenges of modernization. - M., 2007 .-- 214 p.

3. Alimdjanov H.G. The National Program for Personnel Training of the Republic of Uzbekistan and the issues of its financial support: Written to earn a degree... dis. abstract - T. 2004. - 23 p.

4. Zapolskaya V.V. Non-productive sphere in the USSR / V.V. Zapolskaya - Voronezh: Voronezh State University, 1996. - P.50-55

5. Kalmetov B.D. Educational complex in a market economy. - Toshkent: Adolat, $2003 .--499$ p.

6. Noskov V.A. High school in the system of social reproduction. Abstract. Dis. on soch uch. Ph.D. Kostroma - 2003.38 s.

7. Saidov M.Kh. Economics, investments and marketing of higher education. -T. Moliya, 2002 .-- 332 p.

8. Umarov I., Rezhapov H.Kh. "International ratings and the rating system of Uzbekistan" / Materials of the international scientific-practical conference on the topic "Actual issues of modern science and education" Issue No. 14. Volume 1. Kirov 2015. Page 432-437.

9. Kurbonov Sh.E., Seytkhalilov E.A. National model and training program - achievement and result of independence of Uzbekistan. - T : Marifat - Madadkor 2003 .-- 656 p.

10. State Inspection on Education Quality Control under the Cabinet of Ministers of the Republic of Uzbekistan

11. Data from the State Inspectorate for Educational Quality Control under the Cabinet of Ministers of the Republic of Uzbekistan 